International Business and Global Economy 2018, no. 37, pp. 374-385

Biznes międzynarodowy w gospodarce globalnej 2018, nr 37, s. 374-385

Edited by the Institute of International Business, University of Gdańsk

\title{
Determinanty działalności przedsiębiorstw międzynarodowych z krajów OECD w Polsce
}

Celem niniejszego artykułu jest empiryczne zbadanie determinant działalności przedsiębiorstw międzynarodowych pochodzących z krajów OECD w Polsce w okresie 1990-2015 przy użyciu modelu dwumianowego ujemnego z uwzględnieniem indywidualnych efektów stałych i losowych dla poszczególnych krajów macierzystych oraz bez ich uwzględnienia. Badanie jest prowadzone w odniesieniu do tzw. nowej teorii przedsiębiorstwa międzynarodowego (NTPM), która pozwala na wyprowadzenie szeregu hipotez badawczych i rozróżnienie między poziomymi oraz pionowymi motywami dokonywania zagranicznych inwestycji bezpośrednich (ZIB). Z przeprowadzonych badań empirycznych wynika, że Polska przyciąga zarówno poziome, jak i pionowe inwestycje motywowane odpowiednio dostępem do rynku kraju goszczącego oraz chęcią redukcji kosztów. Ponadto, z przeprowadzonych badań wynika również, że przedsiębiorstwa międzynarodowe pochodzące $z$ krajów członkowskich UE są bardziej zaangażowane $w$ prowadzenie działalności w Polsce niż inwestorzy z pozostałych krajów OECD.

Słowa kluczowe: model dwumianowy ujemny, OECD, Polska, przedsiębiorstwa międzynarodowe Klasyfikacja JEL: F23, P33

\section{Determinants of the activity of multinational OECD enterprises in Poland}

The aim of the paper is to study empirically the determinants of the activity of multinational OECD enterprises in Poland in the period 1990-2015 using the negative binomial model without and with accounting for individual fixed and random effects for particular home countries. The research is conducted with reference to the so-called new theory of the multinational enterprise (NTME) that allows to derive a number of empirically testable hypotheses and distinguish between horizontal and vertical motives for undertaking foreign direct investment (FDI). The assembled empirical evidence shows that Poland attracts both horizontal and vertical investment motivated by host country market access and cost reduction motives, respectively. In addition, empirical evidence shows that multinational enterprises from the EU are more involved in production activity in Poland compared to investors from other OECD countries.

Keywords: negative binomial model, OECD, Poland, multinational enterprises

JEL classification: F23, P33 


\section{Wprowadzenie}

Przedsiębiorstwa międzynarodowe, które poprzez swoje filie prowadzą działalność w wielu krajach, odgrywają istotną rolę w coraz bardziej zintegrowanej gospodarce światowej. Wraz ze wzrostem ich znaczenia ewolucji ulega również struktura dokonywanych przez nie zagranicznych inwestycji bezpośrednich (ZIB). Tradycyjne teorie międzynarodowych przepływów kapitałowych nie są $\mathrm{w}$ stanie poprawnie wyjaśnić zakresu oraz struktury działalności przedsiębiorstw międzynarodowych, a zmieniający się $w$ czasie charakter ZIB motywuje kolejne wysiłki mające na celu wyjaśnienie ich determinant. Ponadto, otwarcie gospodarek krajów Europy Środkowej i Wschodniej na napływ ZIB na przełomie lat osiemdziesiątych i dziewięćdziesiątych XX w. spowodowało zwiększenie zainteresowania determinantami ZIB również $\mathrm{w}$ tych krajach.

W ciągu ostatniego ćwierćwiecza nastąpił istotny wzrost napływu ZIB do krajów rozwijających się i transformujących, w tym również Polski. Obecnie Polska jest jednym z najważniejszych odbiorców zagranicznego kapitału wśród krajów członkowskich Unii Europejskiej. Przykładowo, według danych Narodowego Banku Polskiego [NBP, 2017] w 2015 r. zobowiązania Polski z tytułu ZIB wyniosły 712,1 mld PLN. Największe zobowiązania odnotowano wobec inwestorów z Holandii (129,3 mld PLN), Niemiec (116,6 mld PLN) oraz Luksemburga (82,2 mld PLN). Uwzględniając perspektywę kraju siedziby podmiotu dominującego w grupie kapitałowej, największym inwestorem bezpośrednim w Polsce są Niemcy (135,9 mld PLN), natomiast kolejne miejsca zajmują Stany Zjednoczone (77,3 mld PLN) oraz Francja (76,9 mld PLN).

Celem niniejszego artykułu jest zbadanie determinant działalności przedsiębiorstw międzynarodowych pochodzących z krajów OECD w Polsce w okresie 1990-2015 przy użyciu modelu dwumianowego ujemnego. Badanie to jest prowadzone w nawiązaniu do tzw. nowej teorii przedsiębiorstwa międzynarodowego (NTPM), która pozwala na rozróżnienie między poziomymi oraz pionowymi motywami dokonywania ZIB w Polsce przez inwestorów pochodzących z innych krajów OECD, a tym samym na lepsze zrozumienie ich przyczyn.

W pierwszej części artykułu przedstawiono przegląd literatury, w drugiej hipotezy badawcze oraz dane statystyczne, natomiast $w$ trzeciej wyniki badań empirycznych. Wnioski końcowe oraz wskazówki dla przyszłych badań zawarte zostały $\mathrm{w}$ podsumowaniu. 


\section{Przegląd literatury}

W teoretycznej literaturze przedmiotu, określanej mianem tzw. nowej teorii przedsiębiorstwa międzynarodowego, występują dwa główne nurty. Pierwszy $\mathrm{z}$ nich koncentruje się na poziomych ZIB, natomiast drugi - na pionowych. Poziome ZIB związane są z tworzeniem od podstaw bądź też nabywaniem za granicą już istniejących zakładów w tych samych gałęziach co w kraju macierzystym. Oznacza to, że zagraniczne filie wytwarzają te same bądź podobne produkty co firmy macierzyste. Natomiast pionowe ZIB wiążą się z rozbiciem łańcucha wartości w skali międzynarodowej oraz lokowaniem różnych stadiów procesów produkcji w poszczególnych krajach w oparciu o ich przewagi komparatywne. Oznacza to, że przedsiębiorstwa międzynarodowe w części swoich filii produkują dobra lub usługi wykorzystywane jako nakłady $w$ innych prowadzonych przez siebie rodzajach działalności.

Nurt poświęcony poziomym ZIB zapoczątkowany został pracami Krugmana [1983] i Markusena [1984], które rozwinęli następnie m.in. Horstmann i Markusen [1987; 1992], Markusen i Venables [1998; 2000], Sinha [2010], Collie [2011], a także Cieślik [2013; 2015a; 2015b; 2016]. Natomiast nurt poświęcony pionowym ZIB, zapoczątkowany przez Krugmana [1983], Helpmana [1984] oraz Helpmana i Krugmana [1985], kontynuowali m.in. Zhang i Markusen [1999] oraz Markusen [2002]. Te prace pokazały, w jakich warunkach dochodzi do zaistnienia poziomych bądź pionowych ZIB w zależności od indywidualnych atrybutów krajów goszczących oraz krajów macierzystych, takich jak absolutna oraz relatywna wielkość rynku czy relatywne wyposażenie w zasoby czynników produkcji.

W świetle powyższych prac poziome ZIB motywowane są chęcią uzyskania dostępu do rynku w kraju goszczącym i mają miejsce w sytuacji, gdy koszty handlu pomiędzy krajami są wysokie, kraje są podobne pod względem wielkości rynku, a koszty prowadzenia działalności w obu krajach są zbliżone. Z kolei pionowe ZIB motywowane są chęcią wykorzystania różnic $\mathrm{w}$ relatywnych wynagrodzeniach czynników produkcji między krajami i dokonywane są w sytuacji, gdy różnice $\mathrm{w}$ relatywnym wyposażeniu w te czynniki są dostatecznie duże, natomiast koszty handlu i koordynacji działalności między krajami są dostatecznie niskie.

Bardzo ważnym osiągnięciem NTPM było opracowanie podejścia zintegrowanego, łączącego w sobie cechy dwóch wyżej wymienionych podejść w ramach jednego uogólnionego modelu teoretycznego. Model ten, zwany modelem kapitału wiedzy, opracowany został przez Markusena [1997; 2002]. W tym modelu mogą następować zarówno poziome, jak i pionowe ZIB w zależności od zestawu atrybutów kraju goszczącego i kraju macierzystego. Wcześniejsze modele poziomych i pionowych ZIB można postrzegać jako jego szczególne przypadki ${ }^{1}$.

\footnotetext{
1 Omówienie tego modelu zob. [Cieślik, 2017a].
} 
W kolejnych latach model kapitału wiedzy rozszerzyło wielu autorów, m.in. Bergstrand i Egger [2007, 2013], Markusen i Strand [2009], Markusen i Stähler [2011] oraz Chen, Horstmann i Markusen [2012].

Jedno z najważniejszych rozszerzeń oryginalnego modelu Markusena polegało na wprowadzeniu do niego dodatkowego czynnika produkcji, jakim był kapitał fizyczny, obok kapitału ludzkiego i pracy niewykwalifikowanej. Rozszerzenie to pozwala na dokonywanie bezpośrednich porównań modelu kapitału wiedzy $\mathrm{z}$ modelami poziomych oraz pionowych ZIB, $\mathrm{w}$ których różnice $\mathrm{w}$ relatywnym wyposażeniu $\mathrm{w}$ zasoby czynników produkcji były określane przez stosunki nakładów kapitału fizycznego do nakładów prostej pracy.

Empiryczne badania czynników określających wielkość zagranicznego zaangażowania przedsiębiorstw międzynarodowych $\mathrm{w}$ krajach goszczących $\mathrm{w}$ nawiązaniu do NTPM mają swój początek dopiero w latach dziewięćdziesiątych XX w. Badania w tej dziedzinie zapoczątkowała Brainard [1993; 1997] i dotyczyły one początkowo przedsiębiorstw amerykańskich. Z przeprowadzonych przez nią badań wynikało, że zdecydowana większość przedsiębiorstw amerykańskich dokonywała poziomych, a nie pionowych ZIB. W dalszych badaniach empirycznych Carr, Markusen i Maskus [2001] odwołali się do modelu kapitału wiedzy, uzyskując wyniki potwierdzające istnienie zarówno poziomych, jak i pionowych ZIB, chociaż wyniki ich badań były kwestionowane $\mathrm{w}$ dalszych pracach innych autorów ${ }^{2}$.

W późniejszych latach badaniami empirycznymi objęto również przedsiębiorstwa międzynarodowe pochodzące z innych krajów niż Stany Zjednoczone dokonujące inwestycji bezpośrednich w różnych grupach krajów goszczących. Badania empiryczne dla krajów Europy Środkowej i Wschodniej prowadzone były dla regionu jako całości, jak również w kontekście poszczególnych krajów. Empiryczne badania czynników określających wielkość ZIB w regionie prowadzili m.in. Cieślik [1996], Lansbury, Pain i Smidkova [1996], Brenton Di Mauro i Lucke [1999], Benacek i in. [2000], Resmini [2000], Garibaldi i in. [2001], Bevan i Estrin [2004], Carstensen i Toubal [2004], Cieślik i Ryan [2004], Baniak, Cukrowski i Herczyński [2005], Gorbunova, Infante i Smirnova [2012], Wach i Wojciechowski [2016], a ostatnio także Tang [2017].

Z kolei badania dotyczące determinant działalności przedsiębiorstw międzynarodowych w Polsce prowadzili m.in. Witkowska [1996], Przybylska [1998], Liberska [1999], Polak [2002], Markowicz i Miłaszewicz [2007], Ancyparowicz [2009], Torrisi i in. [2009], Lizińska [2012] oraz ostatnio także Cieślik [2017b; 2017c]. Większość powyższych prac nie nawiązuje jednak do NTPM i nie stara się dokonać rozróżnienia między pionowymi i poziomymi motywami dokonywania ZIB. Z tego powodu niniejsza praca stara się wypełnić część luki w dotychczasowej literaturze przedmiotu. W szczególności, niniejszy artykuł rozszerza wcześniejsze

2 Przegląd badań empirycznych zob. [Cieślik, 2017a]. 
empiryczne prace Cieślika [2017b; 2017c], poświęcone działalności w Polsce przedsiębiorstw międzynarodowych pochodzących z krajów UE, na szerszą grupę krajów OECD obejmującą kraje pozaeuropejskie.

\section{Hipotezy badawcze i dane statystyczne}

Przedmiotem empirycznej weryfikacji będą następujące szczegółowe hipotezy badawcze wyprowadzone z teoretycznego modelu kapitału wiedzy, łączącego w sobie poziome i pionowe motywy dokonywania ZIB:

H1: Liczba przedsiębiorstw międzynarodowych jest pozytywnie skorelowana $\mathrm{z}$ absolutną oraz relatywną wielkością rynku Polski oraz jej partnerów inwestycyjnych (motyw horyzontalny).

H2: Większe różnice pod względem relatywnego wyposażenia między Polską a jej partnerami inwestycyjnymi przyczyniają się do zwiększenia liczby przedsiębiorstw międzynarodowych działających w Polsce (motyw wertykalny).

H3: Niższe koszty handlu między Polską a jej partnerami inwestycyjnymi prowadzą do zwiększenia liczby przedsiębiorstw międzynarodowych działających w Polsce (motyw wertykalny) lub jej zmniejszenia (motyw horyzontalny).

H4: Niższe koszty prowadzenia działalności przedsiębiorstw międzynarodowych w Polsce prowadzą do zwiększenia ich liczby (motyw horyzontalny i wertykalny).

Absolutna oraz relatywna wielkość rynku Polski i jej partnera inwestycyjnego mierzone są odpowiednio za pomocą sumy (Suma $P K B$ ) oraz kwadratu różnicy ich PKB (różnica PKB) ${ }^{2}$, a różnice $\mathrm{w}$ relatywnym wyposażeniu w czynniki produkcji za pomocą absolutnych wartości różnic w kapitale fizycznym (Różnica KF) oraz w kapitale ludzkim (Różnica $K L$ ) na zatrudnionego. Te zmienne objaśniające pochodzą z Penn World Table (PWT) 9.0 dostępnej online na stronie www.ggdc.net/pwt, natomiast koszty handlu przybliżane są za pomocą fizycznej odległości geograficznej między Warszawą a stolicą danego partnera inwestycyjnego. Odległości te obliczone zostały przy użycia kalkulatora odległości dostępnego na stronie www.indo.com/distance. W celu uwzględnienia roli kosztów prowadzenia działalności gospodarczej w szacowanym równaniu uwzględniona zostanie również zmienna wskaźnikowa opisująca członkostwo partnera inwestycyjnego w UE $(U E)$, która przyjmuje wartość $0 \mathrm{w}$ okresie, w którym partner nie był członkiem UE, oraz wartość $1 \mathrm{w}$ okresie, w którym był on jej członkiem.

W szacowanym równaniu zmienną zależną jest liczba działających w Polsce przedsiębiorstw międzynarodowych pochodzących z krajów OECD. Dane dotyczące tej liczby pochodzą z wydawnictw Głównego Urzędu Statystycznego pod tytułem Działalność gospodarcza podmiotów z kapitałem zagranicznym. Liczba ta przyjmuje nieujemne wartości całkowite, a rozkład przedsiębiorstw jest skrzywiony na 
korzyść niektórych krajów z tzw. starej Unii. Z tego względu w badaniu empirycznym uzasadnione jest zastosowanie modeli liczebności, a w szczególności modelu Poissona lub modelu dwumianowego ujemnego.

Model Poissona zakłada równość dwóch pierwszych momentów: wartości oczekiwanej i wariancji. W rzeczywistości założenie to rzadko bywa spełnione z powodu występowania zjawiska tzw. nadmiernej dyspersji. Oznacza to, że wariancja jest większa od wartości średniej, stąd częściej wykorzystuje się rozszerzenie modelu Poissona, jakim jest model dwumianowy ujemny. Model ten dąży do modelu Poissona w miarę tego, jak dyspersja dąży do zera. Do porównania obydwu modeli można wykorzystać standardowy test stosunku wiarygodności LR, który określa zasadność zastosowania jednego z nich. Wrażliwość wyników estymacji uzyskanych za pomocą podstawowego modelu dwumianowego ujemnego zostanie zbadana przy użyciu estymatorów efektów stałych i losowych.

Procedura identyfikacji motywów dokonywania ZIB w Polsce opiera się na znakach parametrów towarzyszących zmiennym objaśniającym oraz ich statystycznej istotności. Przykładowo, statystycznie istotny dodatni znak towarzyszący zmiennej mierzącej relatywną wielkość rynku zbytu będzie stanowił potwierdzenie motywu poziomego, natomiast statystycznie istotny dodatni znak towarzyszący zmiennej mierzącej różnice pod względem relatywnego wyposażenia $\mathrm{w}$ zasoby czynników produkcji będzie stanowił potwierdzenie motywu pionowego.

Próba obejmuje 34 kraje członkowskie OECD i dotyczy okresu 1990-2015, co łącznie daje 884 obserwacje. W celu uniknięcia potencjalnego problemu endogeniczności zmienne objaśniające, z wyjątkiem odległości oraz członkostwa w UE, zostały opóźnione o jeden okres. Podstawowe statystyki zmiennych wykorzystanych w badaniu empirycznym zamieszczone zostały w tabeli 1 .

Tabela 1. Podstawowe statystyki

\begin{tabular}{|l|r|r|r|r|}
\hline \multicolumn{1}{|c|}{ Zmienna } & $\begin{array}{r}\text { Wartość } \\
\text { średnia }\end{array}$ & $\begin{array}{c}\text { Odchylenie } \\
\text { standardowe }\end{array}$ & $\begin{array}{c}\text { Wartość } \\
\text { minimalna }\end{array}$ & $\begin{array}{c}\text { Wartość } \\
\text { maksymalna }\end{array}$ \\
\hline Firmy międzynarodowe & 426,0781 & 917,8719 & 0 & 6303 \\
\hline Suma PKB & 1648038 & 2352042 & 306801,6 & $1,77 \mathrm{e}+07$ \\
\hline (różnica PKB) $^{2}$ & $5,61 \mathrm{e}+14$ & $2,89 \mathrm{e}+15$ & $1,05 \mathrm{e}+08$ & $2,48 \mathrm{e}+16$ \\
\hline Różnica KL & 0,3179 & 0,2258 & 0,0009 & 1,0447 \\
\hline Różnica KF & 139306,6 & 84567,4 & 130,3549 & 421443,3 \\
\hline Odległó́ć & 3494,059 & 4513,42 & 515 & 17682 \\
\hline UE & 0,5056 & 0,5002 & 0 & 1 \\
\hline
\end{tabular}

Źródło: Opracowanie własne. 


\section{Wyniki estymacji}

W niniejszej części artykułu przedstawiono wyniki badań empirycznych uzyskane przy użyciu modelu dwumianowego ujemnego, które zamieszczone zostały w tabeli 2 .

Tabela 2. Wyniki estymacji

\begin{tabular}{|l|l|l|l|}
\hline \multicolumn{1}{|c|}{ Zmienne objaśniające } & \multicolumn{1}{|c|}{$(1)$} & \multicolumn{1}{c|}{$(2)$} & \multicolumn{1}{c|}{$(3)$} \\
\hline Stała & $\begin{array}{l}2,7839^{* * *} \\
(22,17)\end{array}$ & $\begin{array}{l}-0,4201^{* * *} \\
(3,96)\end{array}$ & $\begin{array}{l}-1,6842^{* * *} \\
(12,75)\end{array}$ \\
\hline \multirow{2}{*}{ Suma PKB } & $\begin{array}{l}6,85 \mathrm{e}-07^{* * *} \\
(13,06)\end{array}$ & $\begin{array}{l}5,47 \mathrm{e}-07^{* * *} \\
(16,69)\end{array}$ & $\begin{array}{l}3,40 \mathrm{e}-08 \\
(0,67)\end{array}$ \\
\hline \multirow{2}{*}{ (różnica PKB) ${ }^{2}$} & $\begin{array}{l}-4,07 \mathrm{e}-16^{* * *} \\
(10,26)\end{array}$ & $\begin{array}{l}-2,46 \mathrm{e}-16^{* * *} \\
(15,83)\end{array}$ & $\begin{array}{l}-1,07 \mathrm{e}-17 \\
(0,39)\end{array}$ \\
\hline \multirow{2}{*}{ Różnica KL } & $\begin{array}{l}0,6982^{* * *} \\
(3,81)\end{array}$ & $\begin{array}{l}0,5952^{* * *} \\
(3,79)\end{array}$ & $\begin{array}{l}0,2708^{* *} \\
(1,89)\end{array}$ \\
\hline \multirow{2}{*}{ Różnica KF } & $\begin{array}{l}9,63 \mathrm{e}-06^{* * *} \\
(15,84)\end{array}$ & $\begin{array}{l}3,86 \mathrm{e}-06^{* * *} \\
(13,05)\end{array}$ & $\begin{array}{l}7,31 \mathrm{e}-06^{* * *} \\
(19,45)\end{array}$ \\
\hline \multirow{2}{*}{ Odległość } & $\begin{array}{l}-0,0001^{* * *} \\
(18,51)\end{array}$ & $\begin{array}{l}0,0001^{* * *} \\
(3,47)\end{array}$ & $\begin{array}{l}0,0003^{* * *} \\
(20,71)\end{array}$ \\
\hline \multirow{2}{*}{ UE } & $\begin{array}{l}0,8081^{* * *} \\
(8,16)\end{array}$ & $\begin{array}{l}0,4807^{* * *} \\
(5,97)\end{array}$ & $\begin{array}{l}0,4948^{* * *} \\
(4,28)\end{array}$ \\
\hline Efekty indywidualne & brak & stałe & losowe \\
\hline \multirow{2}{*}{$\alpha$} & $\begin{array}{l}1,1033^{* * *} \\
(22,4992)\end{array}$ & & \\
\hline Test LR & $2,0 \mathrm{e}+05$ & & $-5446,1232$ \\
\hline (wartość p) & $(0,000)$ & $-4392,3605$ & \\
\hline Logartym wiarogodności & $-5402,3175$ & & \\
\hline
\end{tabular}

*** statystycznie istotny na poziomie $1 \%,{ }^{* *}$ statystycznie istotny na poziomie $5 \%,{ }^{*}$ statystycznie istotny na poziomie $10 \%$

Źródło: Opracowanie własne.

W kolumnie (1) tabeli 2 przedstawione zostały wyniki bazowe uzyskane za pomocą podstawowej wersji modelu dwumianowego ujemnego bez uwzględnienia efektów indywidualnych dla poszczególnych krajów OECD będących partnerami inwestycyjnymi Polski. Otrzymane wartości oszacowanego parametru $\alpha$, który jest statystycznie większy od zera, oraz testu LR potwierdzają jednoznacznie zasadność zastosowania modelu dwumianowego ujemnego ze względu na występowanie zjawiska nadmiernej dyspersji w danych statystycznych. Z kolei wszystkie uzyskane znaki parametrów towarzyszących zmiennym objaśniającym są zgodne z oczekiwaniami, natomiast wszystkie zmienne są statystycznie istotne już na poziomie 1\% statystycznej istotności. 
W szczególności, wielkość zaangażowania przedsiębiorstw międzynarodowych jest pozytywnie skorelowana zarówno z absolutną, jak i relatywną wielkością rynku Polski oraz jej partnerów inwestycyjnych, co potwierdza występowanie motywu poziomego w przypadku ZIB dokonywanych w Polsce. Z kolei dodatni i statystycznie istotny współczynnik towarzyszący zmiennej opisującej różnice w kapitale ludzkim między Polską a jej partnerem inwestycyjnym potwierdza występowanie motywu pionowego. Podobnie, współczynnik towarzyszący zmiennej mierzącej różnice $\mathrm{w}$ relatywnym wyposażeniu w kapitał fizyczny na pracownika między Polską a jej partnerem inwestycyjnym jest dodatni i statystycznie istotny, co dodatkowo potwierdza występowanie motywu pionowego. Sugeruje to zatem, że różnice występujące między krajami zarówno w relatywnym wyposażeniu w czynniki produkcji, takie jak kapitał ludzki, jak i w wyposażeniu w kapitał fizyczny odgrywają istotną rolę w kształtowaniu wielkości zaangażowania przedsiębiorstw międzynarodowych pochodzących z krajów OECD na terenie Polski.

Na motyw pionowy wskazuje ponadto ujemny znak towarzyszący statystycznie istotnej zmiennej mierzącej odległość geograficzną między Polską a jej partnerem inwestycyjnym. Z kolei oszacowany parametr towarzyszący zmiennej wskaźnikowej opisującej członkostwo w UE partnera inwestycyjnego Polski jest dodatni i statystycznie istotny, co oznacza, że przedsiębiorstwa międzynarodowe pochodzące z krajów UE są bardziej zaangażowane w prowadzenie działalności w Polsce niż inwestorzy z pozostałych krajów OECD, nawet po uwzględnieniu roli odległości geograficznej.

W celu zbadania wrażliwości wyników uzyskanych za pomocą podstawowej wersji modelu dwumianowego ujemnego bez uwzględnienia efektów indywidualnych dla poszczególnych krajów OECD w kolumnie (2) przedstawione zostały wyniki uzyskane przy użyciu estymatora efektów stałych. Wyniki te są jednak bardzo podobne do wyników zamieszczonych w kolumnie (1) i nie prowadzą do zmiany wcześniej wyciągniętych wniosków, ponieważ wszystkie oszacowane parametry pozostają statystycznie istotne na poziomie $1 \%$ i w zdecydowanej większości zachowują swoje poprzednie znaki. W szczególności potwierdzają one występowanie zarówno poziomego, jak i pionowego motywu dokonywania ZIB w Polsce przez przedsiębiorstwa międzynarodowe pochodzące z krajów OECD. Jedyna istotna różnica polega na zmianie znaku oszacowanego współczynnika towarzyszącego zmiennej mierzącej odległość geograficzną między krajami, który obecnie staje się dodatni, co wskazywałoby na motyw poziomy dokonywania ZIB.

Z kolei w kolumnie (3) przedstawione zostały wyniki estymacji uzyskane za pomocą estymatora efektów losowych. Uwzględnienie tych efektów sprawia, że pewnej modyfikacji ulegają wnioski wyciągnięte na podstawie wcześniejszych oszacowań. Statystyczną istotność tracą zwłaszcza zmienne mierzące absolutną 
oraz relatywną wielkość rynku Polski oraz jej partnerów inwestycyjnych, co sugerowałoby zanik motywu poziomego w przypadku ZIB dokonywanych w Polsce. Jednak oszacowany współczynnik towarzyszący zmiennej mierzącej odległość geograficzną między krajami nadal pozostaje dodatni i statystycznie istotny na poziomie $1 \%$, co potwierdza znaczenie motywu poziomego.

Oszacowany współczynnik towarzyszący zmiennej mierzącej różnice w wyposażeniu w kapitał ludzki co prawda zachowuje dodatni znak, ale staje się statystycznie istotny na poziomie 5\%. Natomiast oszacowany współczynnik towarzyszący różnicom $\mathrm{w}$ wyposażeniu $\mathrm{w}$ kapitał fizyczny nadal posiada dodatni znak i pozostaje statystycznie istotny na poziomie $1 \%$. Nie zmienia to zatem $\mathrm{w}$ zasadniczy sposób wcześniejszych konkluzji dotyczących roli różnic w relatywnym wyposażeniu w zasoby czynników produkcji i znaczenia pionowego motywu dokonywania ZIB w Polsce.

\section{Podsumowanie}

Celem niniejszego artykułu było zbadanie determinant działalności przedsiębiorstw międzynarodowych pochodzących z krajów OECD w Polsce w okresie 1990-2015 przy użyciu modelu dwumianowego ujemnego. Badanie to przeprowadzone zostało $\mathrm{w}$ nawiązaniu do nowej teorii przedsiębiorstwa międzynarodowego. Przedmiotem empirycznej weryfikacji były przede wszystkim hipotezy wyprowadzone z modelu kapitału wiedzy, w którym połączone zostały poziome oraz pionowe motywy dokonywania ZIB.

Uzyskane wyniki estymacji nie dały podstaw do odrzucenia postawionych hipotez badawczych. W szczególności stwierdzić można, że ZIB dokonywane w Polsce przez przedsiębiorstwa międzynarodowe pochodzące z krajów OECD mają charakter zarówno poziomy, motywowany chęcią dostępu do polskiego rynku zbytu, jaki pionowy, motywowany różnicami w relatywnym wyposażeniu w zasoby czynników produkcji, które powodują występowanie różnic w kosztach produkcji.

W ramach dalszych badań wskazane byłoby rozszerzenie próby na większą liczbę krajów, a także zbadanie determinant ZIB z krajów rozwijających się. Wskazane byłoby również zbadanie wrażliwości uzyskanych wyników poprzez zastosowanie alternatywnych miar ZIB, takich jak wielkość zainwestowanego kapitału zagranicznego, wielkości sprzedaży przedsiębiorstw międzynarodowych czy też wielkości zatrudnienia w tych przedsiębiorstwach. 


\section{Źródła finansowania}

Niniejsza praca powstała w ramach projektu nr 2015/19/B/HS4/03230 zatytułowanego „Determinanty Bezpośrednich Inwestycji Zagranicznych w Polsce” finansowanego przez Narodowe Centrum Nauki.

\section{Bibliografia}

Ancyparowicz G., 2009, Bezpośrednie inwestycje zagraniczne w Polsce po akcesji do Unii Europejskiej, Zeszyty Naukowe SGGW, Ekonomika i Organizacja Gospodarki Żywnościowej, $\mathrm{nr} 77$.

Baniak A., Cukrowski J., Herczyński J., 2005, On the determinants of foreign direct investment in transition economies, Problems of Economic Transition, vol. 48, no. 2.

Benacek V., Gronicki M., Holland D., Sass M., 2000, The determinants and impact of foreign direct investment in Central and Eastern Europe. A comparison of survey and econometric evidence, Transnational Corporations, vol. 9, no. 3.

Bergstrand J.H., Egger P., 2007, A knowledge and physical capital model of international trade flows, foreign direct investment and multinational enterprises, Journal of International Economics, vol. 73, no. 2.

Bergstrand J.H., Egger P., 2013, Shouldn't physical capital also matter for multinational enterprise activity?, Review of International Economics, vol. 21, no. 5.

Bevan A.A., Estrin S., 2004, The determinants of foreign direct investment into European transition economies, Journal of Comparative Economics, vol. 32, no. 4.

Brainard L.S., 1993, An empirical assessment of the factor proportions explanation of multinational sales, NBER Working Paper, no. 4580.

Brainard L.S., 1997, An empirical assessment of the proximity concentration tradeoff between multinational sales and trade, American Economic Review, vol. 87, no. 4.

Brenton P., Di Mauro F., Lucke M., 1999, Economic integration and FDI. An empirical analysis of foreign investment in the EU and in Central and Eastern Europe, Empirica, vol. 26, no. 2.

Carr D.L., Markusen J.R., Maskus K.E., 2001, Estimating the knowledge capital model of the multinational enterprise, American Economic Review, vol. 91, no. 3.

Carstensen K., Toubal F., 2004, Foreign direct investment in Central and Eastern European countries. A dynamic panel analysis, Journal of Comparative Economics, vol. 32, no. 1.

Chen Y., Horstmann I.J., Markusen J.R., 2012, Physical capital, knowledge capital, and the choice between FDI and outsourcing, Canadian Journal of Economics, vol. 45, no. 1.

Cieślik A., 1996, FDI in Central Europe's Transition. Early Results, Warsaw University Faculty of Economic Sciences Economic Discussion Paper 28, Warsaw.

Cieślik A., 2013, Horizontally integrated MNE and plant heterogeneity, Bank i Kredyt, t. 44, nr 6.

Cieślik A., 2015a, North-North FDI, exporting and the first mover advantage, Bank i Kredyt, t. 46, nr 2.

Cieślik A., 2015b, Imperfect competition, productivity differences and proximity-concentration trade-offs, Ekonomia, $\mathrm{nr} 40$.

Cieślik A., 2016, Exports versus FDI in Smith-Motta framework, Equilibrium. Quarterly Journal of Economics and Economic Policy, vol. 11, no. 2. 
Cieślik A., 2017a, Ewolucja teorii bezpośrednich inwestycji zagranicznych. Przegląd wybranej literatury przedmiotu, [w:] Handel zagraniczny i biznes międzynarodowy we wspótczesnej gospodarce, red. M. Maciejewski, K. Wach, Uniwersytet Ekonomiczny w Krakowie, Kraków.

Cieślik A., 2017b, Determinants of MNE activity in Poland. The case of firms from EU-15, Entrepreneurial Business and Economics Review, vol. 5, no. 1.

Cieślik A., 2017c, Determinanty bezpośrednich inwestycji zagranicznych w Polsce. Czy integracja europejska ma znacznie?, Roczniki Kolegium Analiz Ekonomicznych, t. 47, nr 4.

Cieślik A., Ryan M., 2004, Explaining Japanese direct investment flows into an enlarged Europe. A comparison of gravity and economic potential approaches, Journal of the Japanese and International Economies, vol. 18, no. 1.

Collie D.R., 2011, Multilateral trade liberalization, foreign direct investment and the volume of world trade, Economics Letters, vol. 113, no. 1.

Garibaldi P., Mora N., Sahay R., Zettelmeyer J., 2001, What moves capital to transition economies?, IMF Staff Papers, vol. 48.

Gorbunova Y., Infante D., Smirnova J., 2012, New evidence on FDI determinants. An appraisal over the transition period, Prague Economic Papers, vol. 2.

Helpman E., 1984, A simple theory of trade with multinational corporations, Journal of Political Economy, vol. 92, no. 3 .

Helpman E., Krugman P., 1985, Market structure and foreign trade. Increasing returns, imperfect competition and the international economy, MIT Press, Cambridge MA.

Horstmann I., Markusen J.R., 1987, Strategic investments and the development of multinationals, International Economic Review, vol. 28, no. 1.

Horstmann, I., Markusen J.R., 1992, Endogenous market structures in international trade, Journal of International Economics, vol. 32, no. 1-2.

Krugman P., 1983, The 'New Theories' of International Trade and Multinational Enterprise, [w:] The Multinational Corporation in the 1980s, eds. D.B. Audretsch, Ch.P. Kindleberger, MIT Press, Cambridge MA.

Lansbury M., Pain N., Smidkova K., 1996, Foreign direct investments in Central Europe since 1990. An econometric study, National Institute Economic Review, vol. 156, no. 1.

Liberska B., 1999, Czynniki przyciagające zagraniczne inwestycje bezpośrednie. Wnioski dla Polski z doświadczeń innych krajów, [w:] Kapitat zagraniczny w Polsce. Warunki działania, red. Z. Sadowski, Polskie Towarzystwo Ekonomiczne, Warszawa.

Lizińska W., 2012, Zmiany motywów podejmowania bezpośrednich inwestycji zagranicznych $w$ Polsce, Prace i Materiały Instytutu Handlu Zagranicznego Uniwersytetu Gdańskiego, nr 31 (1).

Markowicz I., Miłaszewicz D., 2007, Analiza determinant bezpośrednich inwestycji zagranicznych w Polsce, Wiadomości Statystyczne, nr 6.

Markusen J.R., 1984, Multinationals, multi-plant economies and the gains from trade, Journal of International Economics, vol. 16, no. 3/4.

Markusen J.R., 1997, Trade versus investment liberalization, NBER Working Paper, no. 6231.

Markusen J.R., 2002, Multinational firms and the theory of international trade, MIT Press, Cambridge M.A.

Markusen J.R., Stähler, F., 2011, Endogenous market structure and foreign market entry, Review of World Economics, vol. 147, no. 2.

Markusen J.R., Strand, B., 2009, Adapting the knowledge-capital model of the multinational enterprise to trade and investment in business services, World Economy, vol. 32, no. 1. 
Markusen J.R., Venables A.J., 1998, Multinational firms and the new trade theory, Journal of International Economics, vol. 46.

Markusen J.R., Venables A.J., 2000, The theory of endowment, intra-industry and multinational trade, Journal of International Economics, vol. 52.

NBP, 2017, Zagraniczne inwestycje bezpośrednie w Polsce i polskie inwestycje bezpośrednie zagranica w 2015 roku, Departament Statystyki NBP, Warszawa.

Polak W., 2002, Determinanty naptywu zagranicznych inwestycji bezpośrednich do Polski w okresie transformacji, Zeszyty Naukowe Akademii Morskiej w Gdyni, nr 43.

Przybylska K., 1998, Czynniki determinujące przyptyw zagranicznych inwestycji bezpośrednich do Polski, Ekonomista, nr 2/3.

Resmini L., 2000, The determinants of Foreign Direct Investment in the CEECs. New evidence from sectoral patterns, Economics of Transition, vol. 8, no. 3.

Sinha U.B., 2010, Strategic licensing, exports, FDI, and host country welfare, Oxford Economic Papers, vol. 62, no. 1.

Tang D., 2017, The determinants of European Union (EU) foreign direct investments in the EU countries from Central and Eastern Europe during 1994-2012, Comparative Economic Research, vol. 20 , no. 1 .

Torrisi C.R., Delaunay C.J., Kocia A., Lubieniecka M., 2009, FDI in Poland. Determinants and implications for countries in transition, Ekonomia, nr 23.

Wach K., Wojciechowski L., 2016, Determinants of inward FDI into Visegrad countries. Empirical evidence based on panel data for the years 2000-2012, Economics and Business Review, vol. 2 , no. 1.

Witkowska J., 1996, Bezpośrednie inwestycje zagraniczne w Europie Środkowowschodniej. Próba interpretacji na gruncie teorii bezpośrednich inwestycji zagranicznych i teorii integracji, Wydawnictwo Uniwersytetu Łódzkiego, Łódź.

Zhang K.H., Markusen J.R., 1999, Vertical multinationals and host-country characteristics, Journal of Development Economics, vol. 59, no. 2.

A. Cieślik ( cieslik@wne.uw.edu.pl

Wydział Nauk Ekonomicznych, Uniwersytet Warszawski, ul. Długa 44/50,

00-241 Warszawa, Polska 